\title{
Node 3 Relocation Environmental Control and Life Support System Modification Kit Verification and Updated Status
}

\author{
David E. Williams ${ }^{1}$ and Lawrence N. Spector ${ }^{2}$ \\ NASA Lyndon B. Johnson Space Center, Houston, TX, 77058
}

\begin{abstract}
Node 1 (Unity) flew to International Space Station (ISS) on Flight 2A. Node 1 was the first module of the United States On-Orbit Segment (USOS) launched to ISS. The Node 1 ISS Environmental Control and Life Support (ECLS) design featured limited ECLS capability. The main purpose of Node 1 was to provide internal storage by providing four stowage rack locations within the module and to allow docking of multiple modules and a truss segment to it. The ECLS subsystems inside Node 1 were routed through the element prior to launch to allow for easy integration of the attached future elements, particularly the Habitation Module which was planned to be located at the nadir docking port of Node 1. After Node 1 was on-orbit, the Program decided not to launch the Habitation Module and instead, to replace it with Node 3 (Tranquility). In 2007, the Program became concerned with a potential Russian docking port approach issue for the Russian FGB nadir docking port after Node 3 is attached to Node 1. To solve this concern the Program decided to relocate Node 3 from Node 1 nadir to Node 1 port. To support the movement of Node 3 the Program decided to build a modification kit for Node 1, an on-orbit feedthrough leak test device, and new vestibule jumpers to support the ECLS part of the relocation. This paper provides a design overview of the modification kit for Node 1, a summary of the Node 1 ECLS re-verification to support the Node 3 relocation from Node 1 nadir to Node 1 port, and a status of the ECLS modification kit installation into Node 1.
\end{abstract}

\section{Introduction}

$\mathrm{T}$ HE ISS Node 1 ECLS System is comprised of five subsystems: Atmosphere Control and Supply (ACS), Atmosphere Revitalization (AR), Fire Detection and Suppression (FDS), Temperature and Humidity Control (THC), and Water Recovery and Management (WRM).

The nominal baseline operation of the Node 1 ACS, AR, FDS, THC, and WRM subsystems capabilities can be subdivided into their sub-allocated functions. The nominal Node 1 ACS consists of: 1) a cabin pressure sensor for monitoring total pressure in the Node 1 cabin, 2) lines for routing low-pressure oxygen $\left(\mathrm{O}_{2}\right)$ and nitrogen $\left.\left(\mathrm{N}_{2}\right), 3\right)$ Joint Airlock Depressurization Pump Assembly (DPA) outlet line, 4) lines for routing high-pressure $\mathrm{O}_{2}$ and $\mathrm{N}_{2}$, and 6) manual pressure equalization valves (MPEVs), which is located in each of the Node 1 hatches, to reduce the pressure differential across the hatch prior to opening the hatch. The nominal Node 1 AR consists of sample lines for routing air samples to the Major Constituent Analyzer (MCA) in the Unites States (U.S.) Laboratory Module or in Node 3. The nominal Node 1 FDS operation includes continuous monitoring for smoke in the Node 1 cabin volume using two redundant area smoke detectors located in the Node 1 THC Inlet Orbital Replacement Unit (ORU) return plenum. The Node 1 cabin air circulation hardware provides the air flow within Node 1 and as part of that function it also moves any cabin smoke particles past the two smoke detectors. The nominal FDS hardware also includes an emergency equipment locker for stowage of the Node 1 portable fire extinguisher (PFE) and portable breathing apparatus (PBA). The original design had the Node 1 port alcove emergency equipment locker as the Node 1 emergency equipment location. A second emergency locker was installed in the starboard alcove of Node 1 but, the internal mounting hardware for the PFE and PBA were not installed in the starboard locker since Node 1 only required a single PFE and PBA per the Node 1 requirements. The starboard emergency locker has become the primary Node 1 emergency equipment location even though the Node 1 PFE and PBA are not as efficiently stowed in the locker without the internal mounting hardware. The nominal Node 1 THC consists of: 1) intramodule

${ }^{1}$ CxP Thermal/ECLS System Integration Group Co-Lead \& C3PO Thermal/ECLS Lead, 2101 NASA Parkway, Mail Stop: EC6, AIAA Member.

${ }^{2}$ Insert Job Title, 2101 NASA Parkway, Mail Stop: EC6.

\author{
1
}

American Institute of Aeronautics and Astronautics 
ventilation, 2) particulate and microbe removal and disposal, and 3) intermodule ventilation (IMV) with adjacent elements including cooling of Node 1, the Cupola, and/or the Mini-Pressurized Logistic Module (MPLM) [the name for the MPLM was changed from Mini-Pressurized Logistic Module to Multi-Purpose Logistic Module later in the Program] with cold IMV air from the U.S. Laboratory Module. The nominal Node 1 WRM consists of: 1) lines for routing excess Space Shuttle Fuel Cell water or Regenerative ECLS Water Processor Assembly (WPA) potable water and 2) lines for routing waste water, i.e. condensate from the non-Russian Segment condensing heat exchangers and waste water from the Extravehicular Activity (EVA) space suits.

The off-nominal baseline operation of the Node 1 ACS, FDS, and THC subsystems capabilities can be subdivided into their sub-allocated functions. The off-nominal ACS hardware includes the PBA quick disconnects (QDs) and the manual pressure equalization valve (MPEV). The PBA QDs provide additional $\mathrm{O}_{2}$ to a crew member by plugging in a PBA extension hose into the PBA and the other end into one of the two $\mathrm{O}_{2}$ distribution PBA QDs. The MPEV is used in nominal and off-nominal ACS operations. In the off-nominal operation it is used to support an emergency response capability by providing a means for repressurizing Node 1 after it had been evacuated to remove any contaminated atmosphere from Node 1. The off-nominal FDS operation hardware includes a PFE for suppressing a fire in Node 1. The PFE is designed so that it can suppress a fire behind the Node 1 closeouts or in the open cabin. Access for the fire suppressant to the volume behind the closeouts is provided by a special PFE nozzle that can penetrate either a $19 \mathrm{~mm}(0.75 \mathrm{inch})$ or a $12.7 \mathrm{~mm}(0.5 \mathrm{inch})$ diameter hole in the closeout panels that is covered by a perforated fire port decal. The off-nominal THC hardware includes the IMV isolation valves which are used to isolate the Node 1 IMV from the adjacent pressurized elements during an emergency event. The exception to this rule is if the Joint Airlock is at reduced pressure while supporting preparations for an EVA then the IMV isolation valves in Node 1 at the Joint Airlock interface are opened to provide a rapid Joint Airlock repressurization capability to allow the crew members in the Joint Airlock to get out and support the emergency response. This capability also requires the ability to be able to turn off the IMV fans and the Inlet ORU in Node 1. This is done to minimize the spreading of smoke/toxic gases between Node 1 and adjacent elements, allows for rapid isolation of the interfaces during a depressurization event, prevents providing fresh air containing oxygen to any fire in Node 1, and it reduces the background noise during a depressurization event.

To support the movement of Node 3 from Node 1 nadir to Node 1 port the Program decided to reroute the low pressure $\mathrm{O}_{2}$ and $\mathrm{N}_{2}$ distribution lines, the air sample distribution line, the waste water distribution line, the fuel cell water line, and the IMV ducting, as described in last year's paper on Node 3 relocation (Ref. 4).

The high-pressure $\mathrm{O}_{2}$ and $\mathrm{N}_{2}$ lines were not rerouted to support this relocation of Node 3 since there are no future plans to support $\mathrm{O}_{2}$ and $\mathrm{N}_{2}$ recharge of the Airlock high pressure gas tanks from a vehicle docked to Pressurized Mating Adapter (PMA 3) / Node 3. Also, there was no change to the Node 1 FDS hardware to support the Node 3 relocation.

\section{Node 1 Modification Overview}

A general overview of the hardware in Node 1 and the modifications that were made to support the relocation of Node 3 is provided below.

\section{A. ACS:}

The Node 1 ACS hardware consists of a single cabin pressure sensor that can monitor the Node 1 cabin pressure between 0 to $104.8 \mathrm{kPa}$ ( 0 to 15.2 psia), low-pressure $\mathrm{O}_{2}$ and $\mathrm{N}_{2}$ distribution lines, low-pressure $\mathrm{O}_{2}$ and $\mathrm{N}_{2}$ manual isolation provided by QDs, a Joint Airlock DPA outlet line, high-pressure $\mathrm{O}_{2}$ and $\mathrm{N}_{2}$ distribution lines, and a single MPEV in each of the six Node 1 hatches. The $\mathrm{O}_{2}$ and $\mathrm{N}_{2}$ distribution lines are made up of hard lines and flexible hoses.

To support the Node 3 relocation the Node 1 low-pressure $\mathrm{O}_{2}$ and $\mathrm{N}_{2}$ distribution lines at the nadir forward location are disconnected at the isolation QD, a new line is attached to the isolation QD, and the new line is then routed to the new Node 1 port location, as shown in Fig. 1.

\section{B. AR:}

The MCA sample distribution lines in Node 1 consists of four electrical 3-way valves, three manual isolation valves, a sample probe, hard lines, and flexible hoses.

To support the Node 3 relocation the Node 1 sample distribution line at the nadir forward location is disconnected at the manual isolation valve, a new line is attached to the manual isolation valve, and the new line is then routed to the new Node 1 port location, as shown in Fig. 1. 


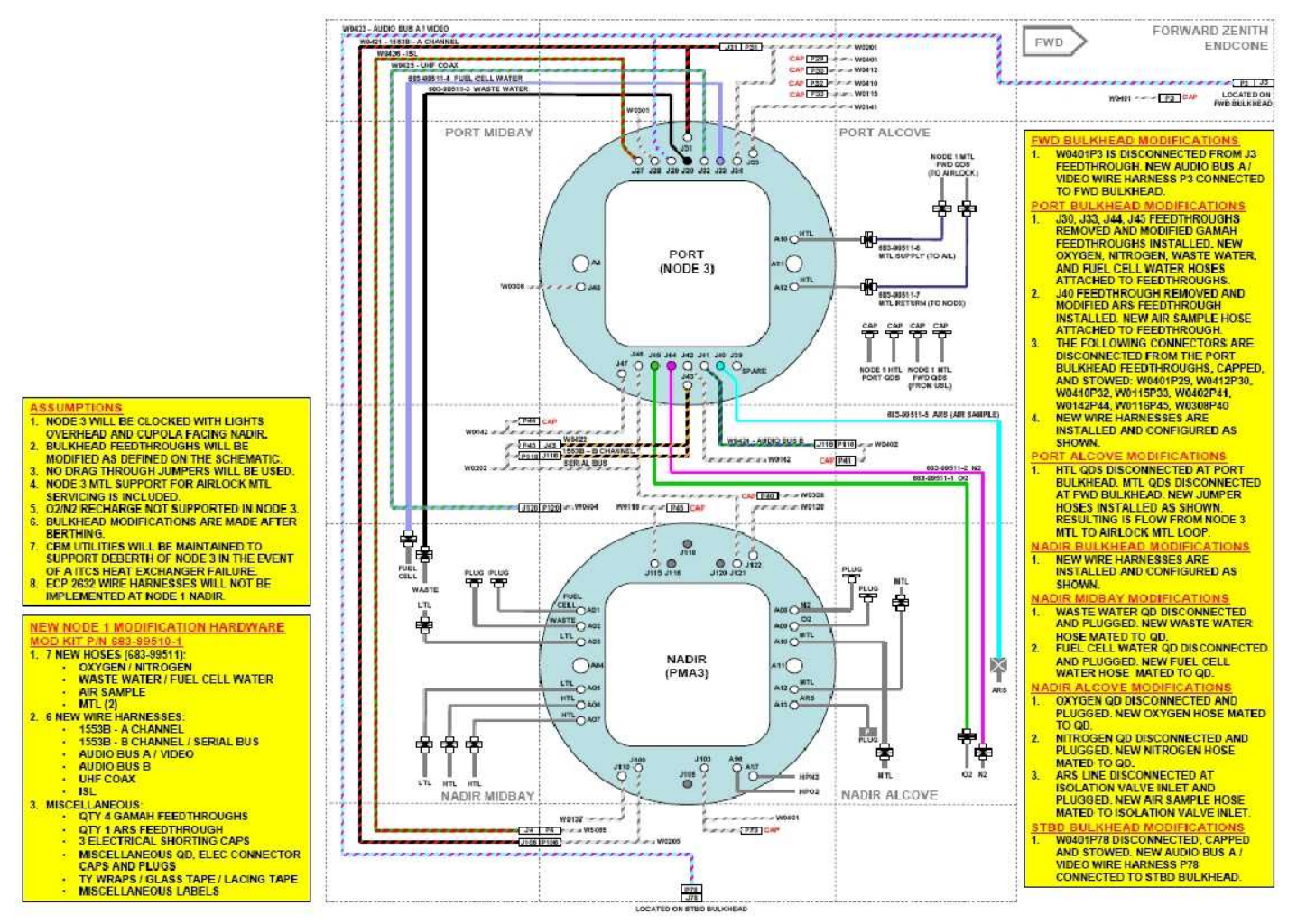

Figure 1. Node 1 Fluid, Data, and Power Line Modification Kit Architecture

\section{THC:}

The Node 1 THC hardware consists of an Inlet Orbital Replacement Unit (ORU); four high efficiency particulate air (HEPA) filters; four cabin air bacteria filter housing assemblies; a plenum that holds the four bacteria filter/housing assemblies, two linear diffusers; four cabin air diffusers; nine IMV isolation valves; IMV fans each with a set of mufflers; one Node 1 air temperature control rheostat; two variable air volume damper assemblies (VAVDAs); three IMV inlet screens; four manual THC isolation valves, flexible air ducting, and hard air ducting made from a composite material.

To support the Node 3 relocation the IMV air to Node 3 was changed from the Node 1 THC Inlet ORU return plenum to a new tee off of the IMV ducting in the Node 1 port/zenith transition area. The IMV design change will allow the Russian Segment (RS) supplied IMV air to be routed to Node 3 or if Node 3 IMV is not active to allow it to be routed to Node 1 or to the U.S. Laboratory Module. Since there was no IMV isolation valve at the Node 1 port aft hatch, the IMV isolation valve at the nadir forward location was moved to that location and a new IMV valve remote manual override (RMO) was added to Node 1 to support this valve re-location, as shown in Fig. 2.

The Node 1 IMV air from Node 3 was changed from the Node 1 nadir forward IMV interface to the port forward IMV interface. This was done by removing the existing port forward IMV fan and silencers, capping the existing port forward damper valve and diffuser, and adding a new flexible ducting to route the IMV air into part of the originally designed IMV air ducting in the nadir forward part of Node 1, as shown in Fig. 2.

\section{WRM:}

The Node 1 WRM consists of the Fuel Cell Water distribution and the Waste Water distribution.

The Fuel Cell Water line runs from the Node 1 forward interface to the Node 1 nadir hatch interface. The lines are made up of hard lines, flexible hoses, and QDs.

The Waste Water line runs from the Node 1 starboard interface to the Node 1 forward interface or to the Node 1 nadir interface. The lines are made up of hard lines, flexible hoses, and QDs.

To support the Node 3 relocation the Node 1 waste water and fuel cell water lines at the nadir midbay location are 


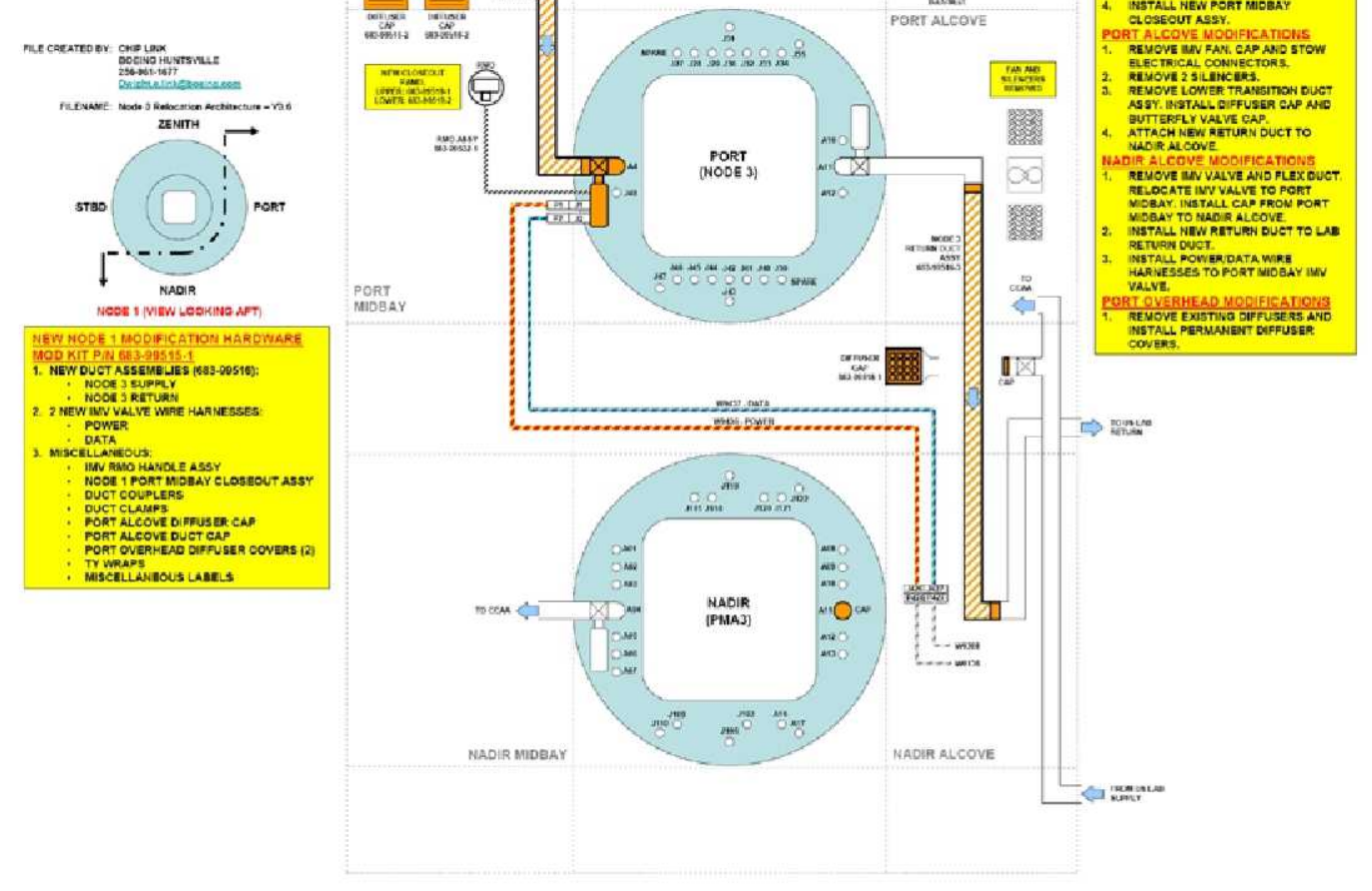

Figure 2. Node 1 THC Modification Kit Architecture

disconnected at the isolation QD, a new line is attached to the isolation QD, and the new line is then routed to the new Node 1 port location, as shown in Fig. 1.

\section{Node 1 Re-Verification Program}

The ECLS design was verified prior to its launch on Flight 2A, as documented in papers from previous years (Ref. 5, 6, and 7). The Node 3 relocation reverification task was a delta element qualification to make sure Node 1still supports Node 3 at its new location, on the port side of Node 1. This was done by verifying that the modification kits as a standalone piece of hardware met the section three requirements in the modification specifications (Ref. 2 and 3). Then the modification kit was verified, when integrated into Node 1, to make sure it then met the section three requirements in the Node 3 relocation specification (Ref. 1), as shown in Fig. 3. The specifications dictates whether a section three requirement is verified by test, analysis, inspection, and/or demonstration, as documented in section four of the specifications. The verification of the ISS hardware is accomplished using a building block process. Verification starts at the component level and progresses until the delta element level verification is complete.

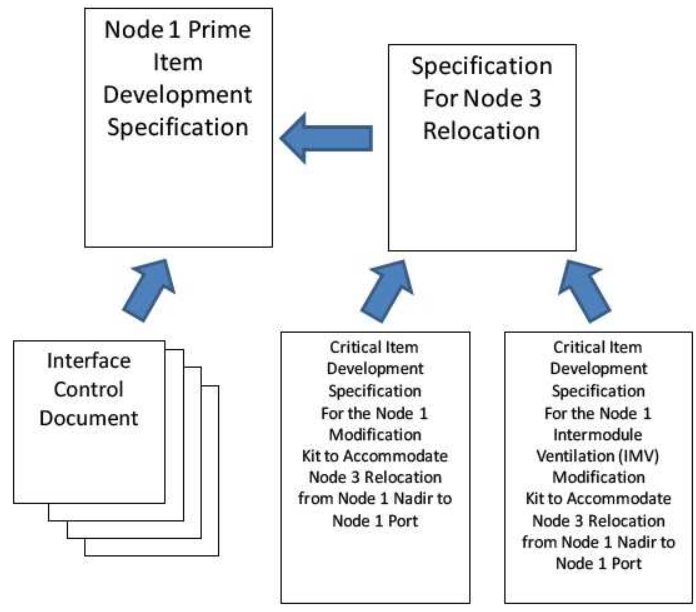

Figure 3. Relationship of Node 1 Specifications with Modification Kit Specifications 


\section{A. Node 1 ACS Re-Verification Methodology:}

\section{Distribute Nitrogen:}

To meet the equipment requirements in Table 1, 2a, and 2b, Boeing Huntsville analyzed the modification kit hose to make sure that the hardware had the proper length, met the proof pressure requirement, met the temperature requirement, and calculated the pressure drop for the new flex hose. They also performed an inspection of the drawings to show that the flex hose was built with the correct connectors at both ends of the hose. The analysis (Ref. 8) and the inspection report (Ref. 9) provided evidence on how these requirements were met.

The analysis showed that the length of the new hose was adequate based on a computer aided drawing (CAD), review of the as built drawing, and a fit check in the Node 1 mockup that was performed on September 4, 2008. It also showed that the proof pressure requirement was met based on a proof pressure test that was conducted by Boeing - Huntsville on July 11, 2009. For the temperature requirement, it was shown to be acceptable based on a review of the hose supplier's thermal cycle test data. The hose pressure loss was calculated to be 0.68 kilopascal (kPa) differential (0.098 psid), which was then used in the system analysis that was performed by Boeing Houston.

The inspection report showed that QD and the gamah fitting on the ends of the hose would mate with the existing Node 1 nitrogen distribution and the new vestibule jumper hose.

Based on the flex hose analysis and inspection results the flex hose met all of its requirements.

To meet the system level requirement in Table 3, Boeing - Houston analyzed the pressure loss of the of the Node 1 low-pressure $\mathrm{N}_{2}$ distribution from the Node 1 starboard interface to the Node 1 port interface at the maximum specified flow rate, temperature, and the initial nominal pressure as specified in the original verification for Node 1 (Ref. 5). The result from the calculated pressure loss analysis for the low-pressure $\mathrm{N}_{2}$ distribution showed that the pressure loss was $4.83 \mathrm{kPa}$ differential $(0.700$ psid) (Ref. 10). This new analysis was performed slightly different than the original Node 1 verification analysis. The difference was that Boeing - Houston used a more realistic friction factor for the flex hoses than the original Node 1 analysis. For this analysis they used a friction factor of two times the friction factor of an equivalent length smooth tube instead of four times that was used in the original verification analysis. Even with the change 
the analysis result is still considered to be slightly conservative since Boeing - Houston used the QD specified pressure drop data in the analysis, which is higher than the actual Qualification data as discussed in the original verification for Node 1.

Based on the analysis result, Node 1 modification kit met the pressure loss requirement for the low-pressure $\mathrm{N}_{2}$ distribution.

\begin{tabular}{|c|c|}
\hline $\begin{array}{c}\text { S683-99600 } \\
\text { Requirement }\end{array}$ & $\begin{array}{l}\text { S683-99600 } \\
\text { Verification }\end{array}$ \\
\hline $\begin{array}{l}\text { The Node } 1 \\
\text { Modification Kit } \\
\text { shall provide a } \\
\text { hose to allow the } \\
\text { interconnection } \\
\text { between the } \\
\text { Node } 1 \text { Nadir } \\
\text { Alcove Nitrogen } \\
\text { Supply connector } \\
\text { and the Node } 1 \\
\text { Port Bulkhead } \\
\text { J44 connector } \\
\text { defined in Table } \\
\text { IX. }\end{array}$ & $\begin{array}{l}\text { An inspection of Node } 1 \\
\text { Modification Kit design drawings } \\
\text { and documentation shall be } \\
\text { performed to show that the Node } \\
1 \text { Modification Kit provides a } \\
\text { hose assembly to allow the } \\
\text { interconnection between the Node } \\
1 \text { Nadir Alcove Nitrogen Supply } \\
\text { connector and the Node } 1 \text { Port } \\
\text { Bulkhead J44 connector defined } \\
\text { in Table IX. The inspection shall } \\
\text { show that the hose assembly end } \\
\text { connectors are compatible } \\
\text { (gender, size and keying) to the } \\
\text { supply/end item connectors } \\
\text { defined in Table IX. The } \\
\text { verification shall be considered } \\
\text { successful when the inspection } \\
\text { shows that the Node } 1 \\
\text { Modification Kit provides a hose } \\
\text { assembly compatible with the } \\
\text { nitrogen interface defined in } \\
\text { Table IX. }\end{array}$ \\
\hline
\end{tabular}

Table 2a. $\mathbf{N}_{2}$ Flex Hose Interconnection Requirement

\begin{tabular}{|c|c|c|}
\hline \multicolumn{3}{|c|}{$\begin{array}{c}\text { S683-99600 } \\
\text { Table IX - } \\
\text { Interface Connector * }\end{array}$} \\
\hline Gender & Size & Keying \\
\hline Male & 0.375 inch & $\begin{array}{c}\text { B (75 } \\
\text { degrees) }\end{array}$ \\
\hline
\end{tabular}

* - Connector at the bulkhead end of the flex hose is a Feedthrough fitting provided by the contractor as part of the Node 1 Modification Kit

\begin{tabular}{|c|c|}
\hline $\begin{array}{c}\text { S684-12964 } \\
\text { Requirement }\end{array}$ & $\begin{array}{l}\text { S684-12964 } \\
\text { Verification }\end{array}$ \\
\hline $\begin{array}{l}\text { Node } 3 \text { Relocation } \\
\text { shall distribute } \\
\text { nitrogen from Node } 1 \\
\text { PORT location to the } \\
\text { Node } 3 \text { interface as } \\
\text { specified in SSP } \\
41140 \text {, paragraph } \\
\text { 3.2.1.2.4. }\end{array}$ & $\begin{array}{l}\text { The Node } 3 \text { Relocation } \\
\text { capability to distribute } \\
\text { nitrogen to the adjacent } \\
\text { elements shall be verified } \\
\text { by analysis. An analysis } \\
\text { shall be conducted to } \\
\text { evaluate nitrogen } \\
\text { pressure loss } \\
\text { characteristics for all the } \\
\text { distributed lines based } \\
\text { upon pressure, } \\
\text { temperature, and flow } \\
\text { interface characteristics } \\
\text { specified in the } \\
\text { appropriate ICDs } \\
\text { referenced requirements } \\
\text { in SSP } 41140 \text {, SSP } \\
41141 \text {, and SSP } 41145 \text {. } \\
\text { Analysis shall similarly } \\
\text { be conducted for } \\
\text { nitrogen distribution } \\
\text { lines during gas transfer } \\
\text { to ISS based upon } \\
\text { pressure, temperature, } \\
\text { and flow interface } \\
\text { characteristics specified } \\
\text { in the appropriate ICDs. } \\
\text { Verification shall be } \\
\text { considered successful } \\
\text { when the analysis proves } \\
\text { that interface conditions } \\
\text { at each adjacent element } \\
\text { port are met as specified } \\
\text { in reference ICDs. }\end{array}$ \\
\hline
\end{tabular}

Table 3. Node $1 \mathrm{~N}_{2}$ Modification Kit Performance Requirement

Table 2b. $\mathrm{N}_{2}$ Flex Hose Interface Connector Requirement 


\section{Distribute Oxygen:}

To meet the equipment requirements in Table 4, 5a, 5b, and 6 Boeing Huntsville analyzed the modification kit hose to make sure that the hardware had the proper length, met the proof pressure requirement, met the temperature requirement, calculated the pressure drop for the new flex hose, and they verified that the oxygen line was at least $5.08 \mathrm{~cm}(2 \mathrm{in}$.) from any power lines. They also performed an inspection of the drawings to show that the flex hose was built with the correct connectors at both ends of the hose. The analysis (Ref. 11 and 12) and the inspection report (Ref. 13) performed provided evidence on how these requirements were met.

The analysis showed that the length of the new hose was adequate based on a CAD drawing, review of the as built drawing, and a fit check in the Node 1 mockup that was performed on September 4, 2008. It also showed that the proof pressure requirement was met based on a proof pressure test that was conducted by Boeing - Huntsville on July 10, 2009. For the temperature requirement, it was shown to be acceptable based on a review of the hose supplier's thermal cycle test data. The hose pressure loss was calculated to be $0.57 \mathrm{kPa}$ differential (0.083 psid), which was then used in the system analysis that was performed by Boeing - Houston. Finally, Boeing Huntsville reviewed the Node 1 modification kit drawings and added a flag note to the drawings to guarantee that the oxygen line had at least $5.08 \mathrm{~cm}$ (2 in.) clearance from any power lines.

The inspection report showed that QD and the gamah fitting on the ends of the hose would mate with the existing Node 1 oxygen distribution and the new vestibule jumper hose.

Based on the flex hose analysis and inspection results the flex hose met all of its requirements.

To meet the system level requirement in Table 7, Boeing - Houston analyzed the pressure loss of the of the Node 1 low-pressure $\mathrm{O}_{2}$ distribution from the Node 1 starboard interface to the Node 1 port interface at the maximum specified flow rate, temperature, and the initial nominal pressure as specified in the original verification for Node 1 (Ref. 5). The result from the calculated pressure loss analysis for the low-pressure $\mathrm{O}_{2}$ distribution showed that the pressure loss was $4.41 \mathrm{kPa}$ differential ( $0.640 \mathrm{psid})$ (Ref. 10). This new analysis was performed slightly different than the original Node 1 verification analysis. The difference was that Boeing - Houston used a more realistic friction factor for the flex hoses than the original Node 1 analysis. For this analysis they used a friction factor of two times the friction factor of an equivalent length smooth tube instead of four times that was used in the original verification analysis. Even with the change the analysis result is still considered to be slightly conservative since 


\begin{tabular}{|c|c|}
\hline $\begin{array}{c}\text { S683-99600 } \\
\text { Requirement }\end{array}$ & $\begin{array}{l}\text { S683-99600 } \\
\text { Verification }\end{array}$ \\
\hline $\begin{array}{l}\text { The Node } 1 \\
\text { Modification Kit } \\
\text { shall provide a hose } \\
\text { to allow the } \\
\text { interconnection } \\
\text { between the Node } 1 \\
\text { Nadir Alcove } \\
\text { Oxygen Supply } \\
\text { connector and the } \\
\text { Node } 1 \text { Port } \\
\text { Bulkhead J45 } \\
\text { connector defined in } \\
\text { Table IX. }\end{array}$ & $\begin{array}{l}\text { An inspection of Node } 1 \\
\text { Modification Kit design } \\
\text { drawings and } \\
\text { documentation shall be } \\
\text { performed to show that } \\
\text { the Node } 1 \text { Modification } \\
\text { Kit provides a hose } \\
\text { assembly to allow the } \\
\text { interconnection between } \\
\text { the Node } 1 \text { Nadir Alcove } \\
\text { Oxygen Supply } \\
\text { connector and the Node } \\
1 \text { Port Bulkhead J45 } \\
\text { connector defined in } \\
\text { Table IX. The } \\
\text { inspection shall show } \\
\text { that the hose assembly } \\
\text { end connectors are } \\
\text { compatible (gender, size } \\
\text { and keying) to the } \\
\text { supply/end item } \\
\text { connectors defined in } \\
\text { Table IX. The } \\
\text { verification shall be } \\
\text { considered successful } \\
\text { when the inspection } \\
\text { shows that the Node } 1 \\
\text { Modification Kit } \\
\text { provides a hose } \\
\text { assembly compatible } \\
\text { with the oxygen } \\
\text { interface defined in } \\
\text { Table IX. }\end{array}$ \\
\hline
\end{tabular}

Table 5a. $\mathrm{O}_{2}$ Flex Hose Interconnection Requirement

\begin{tabular}{|c|c|c|}
\hline \multicolumn{3}{|c|}{$\begin{array}{c}\text { S683-99600 } \\
\text { Requirement - } \\
\text { Interface Connector * }\end{array}$} \\
\hline Gender & Size & Keying \\
\hline Male & 0.375 inch & $\begin{array}{c}\text { F (180 } \\
\text { degrees) }\end{array}$ \\
\hline
\end{tabular}

* - Connector at the bulkhead end of the flex hose is a Feedthrough fitting provided by the contractor as part of the Node 1 Modification Kit

Table 5b. $\mathrm{O}_{2}$ Flex Hose Interface Connector Requirement

\begin{tabular}{|l|l|}
\hline \multicolumn{1}{|c|}{$\begin{array}{c}\text { S683-99600 } \\
\text { Requirement }\end{array}$} & \multicolumn{1}{c|}{$\begin{array}{c}\text { S683-99600 } \\
\text { Verification }\end{array}$} \\
\hline $\begin{array}{l}\text { A two inch clearance } \\
\text { between the Node 1 } \\
\text { Modification Kit } \\
\begin{array}{l}\text { Oxygen hose assembly } \\
\text { and surrounding power } \\
\text { harnesses with EO (120 } \\
\text { or 160 Vdc) or HO (28 } \\
\text { Vdc) classifications will } \\
\text { be maintained } \\
\text { throughout the Node 1. }\end{array}\end{array}$ & $\begin{array}{l}\text { An analysis will be } \\
\text { performed to verify that the } \\
\text { Node 1 Modification Kit } \\
\text { Oxygen hose assembly } \\
\text { clearance between the hose } \\
\text { assembly and surrounding } \\
\text { Node 1 power harnesses } \\
\text { with EO (120 or 160 Vdc) or } \\
\text { HO (28 Vdc) classifications. }\end{array}$ \\
\hline
\end{tabular}

Table 6. O2 Flex Hose Clearance Requirement

\begin{tabular}{|c|c|}
\hline $\begin{array}{c}\text { S684-12964 } \\
\text { Requirement }\end{array}$ & $\begin{array}{l}\text { S684-12964 } \\
\text { Verification }\end{array}$ \\
\hline $\begin{array}{l}\text { Node } 3 \text { Relocation shall } \\
\text { distribute oxygen from } \\
\text { Node } 1 \text { PORT location } \\
\text { to the Node } 3 \text { interface } \\
\text { as specified in SSP } \\
41140 \text {, paragraph } \\
3.2 .1 .2 .3 \text {. }\end{array}$ & $\begin{array}{l}\text { The Node } 3 \text { Relocation } \\
\text { capability to distribute } \\
\text { oxygen to the adjacent } \\
\text { elements shall be verified by } \\
\text { analysis. An analysis shall } \\
\text { be conducted to evaluate } \\
\text { oxygen pressure loss } \\
\text { characteristics for all the } \\
\text { distributed lines based upon } \\
\text { pressure, temperature, and } \\
\text { flow interface characteristics } \\
\text { specified in the appropriate } \\
\text { ICDs referenced } \\
\text { requirements in SSP } 41140 \text {, } \\
\text { SSP 41141, and SSP } 41145 \text {. } \\
\text { Analysis shall similarly be } \\
\text { conducted for conducted for } \\
\text { recharge oxygen distribution } \\
\text { lines during gas transfer to } \\
\text { ISS based upon pressure, } \\
\text { temperature, and flow } \\
\text { interface characteristics } \\
\text { specified in the appropriate } \\
\text { ICDs. } \\
\text { Verification shall be } \\
\text { considered successful when } \\
\text { the analysis proves that } \\
\text { interface conditions at each } \\
\text { adjacent element port are } \\
\text { met as specified in reference } \\
\text { ICDs. }\end{array}$ \\
\hline
\end{tabular}

Table 7. Node $1 \mathrm{O}_{2}$ Modification Kit Performance Requirement 
Boeing - Houston used the QD specified pressure drop data in the analysis, which is higher than the actual Qualification data as discussed in the original verification for Node 1.

Based on the analysis result, Node 1 modification kit met the pressure loss requirement for the low-pressure $\mathrm{O}_{2}$ distribution.

\section{B. Node 1 AR Re-Verification Methodology:}

To meet the equipment requirements in Table 8, 9a, and 9b, Boeing Huntsville analyzed the modification kit hose to make sure that the hardware had the proper length, met the proof pressure requirement, met the temperature requirement, and calculated the pressure drop for the new flex hose. They also performed an inspection of the drawings to show that the flex hose was built with the correct connectors at both ends of the hose. The analysis (Ref. 14) and the inspection report (Ref. 15) performed provided evidence on how these requirements were met.

The analysis showed that the length of the new hose was adequate based on a CAD drawing, review of the hose vendor acceptance data package measurement, and a fit check in the Node 1 mockup that was performed on September 4, 2008. It also showed that the proof pressure and temperature requirements were met based on the hose vendor proof pressure and thermal cycle test data. The hose pressure loss was calculated to be $0.45 \mathrm{kPa}$ differential (0.065 psid), which was then used in the system analysis that was performed by Boeing - Houston.

The inspection report showed that the non-self sealing QD and the swivel nut on the ends of the hose would mate with the existing Node 1 sample air delivery subsystem distribution and the new vestibule jumper hose.

Based on the flex hose analysis and inspection results the flex hose met all of its requirements.

To meet the system level requirement in Table 10, Boeing - Houston analyzed the pressure loss of the of the Node 1 sample distribution line from the Node 1 forward interface to the Node 1 port interface at the maximum specified flow rate, temperature, and the initial nominal pressure as specified in the original verification for Node 1 (Ref. 5). This interface was selected, since it had the smallest margin as documented in the original Node 1 verification results. The other two interfaces, Node 1 sample probe to Node 1 port interface and Node 1 starboard interface to Node 1 port interface, had more margin than the interface that was being reanalyzed. Also, the modified Node 1 sample distribution line was common to all three sample line interfaces.

The result from the calculated pressure loss analysis for this single Node 1 sample distribution line showed that the pressure loss was $1.59 \mathrm{kPa}$ differential ( $0.23 \mathrm{psid}$ ) (Ref. 16). This new analysis was performed slightly different than the original Node 1 verification analysis. The difference was that Boeing - Houston used a more realistic friction factor for the flex hoses than the original Node 1 analysis. For this analysis they used a friction factor of 1.2 the friction factor of an equivalent length smooth tube instead of 4 times that was used in the original verification analysis based on the results from the original U.S. Laboratory Module testing.

American Institute of Aeronautics and Astronautics 
Based on the analysis result, Node 1 modification kit met the pressure loss requirement for the sample distribution line.

\begin{tabular}{|c|c|}
\hline $\begin{array}{c}\text { S683-99600 } \\
\text { Requirement }\end{array}$ & $\begin{array}{l}\text { S683-99600 } \\
\text { Verification }\end{array}$ \\
\hline $\begin{array}{l}\text { The Node } 1 \\
\text { Modification Kit } \\
\text { shall provide a } \\
\text { hose to allow the } \\
\text { interconnection } \\
\text { between the } \\
\text { Node 1 Port } \\
\text { Bulkhead J40 } \\
\text { connector and the } \\
\text { Node 1 Nadir } \\
\text { Alcove ARS } \\
\text { connector } \\
\text { defined in Table } \\
\text { IX. }\end{array}$ & $\begin{array}{l}\text { An inspection of Node } 1 \\
\text { Modification Kit design drawings } \\
\text { and documentation shall be } \\
\text { performed to show that the Node } \\
1 \text { Modification Kit provides a } \\
\text { hose assembly to allow the } \\
\text { interconnection between the Node } \\
1 \text { Port Bulkhead J40 connector } \\
\text { and the Node } 1 \text { Nadir Alcove } \\
\text { ARS connector defined in Table } \\
\text { IX. The inspection shall show } \\
\text { that the hose assembly end } \\
\text { connectors are compatible } \\
\text { (gender, size and keying) to the } \\
\text { supply/end item connectors } \\
\text { defined in Table IX. The } \\
\text { verification shall be considered } \\
\text { successful when the inspection } \\
\text { shows that the Node } 1 \\
\text { Modification Kit provides a hose } \\
\text { assembly compatible with the } \\
\text { ARS interface defined in Table } \\
\text { IX. }\end{array}$ \\
\hline
\end{tabular}

Table 9a. Sample Distribution Line Flex Hose Interconnection Requirement

\section{Node 1 THC Re-Verification Methodology:}

The circulate atmosphere requirements are broken into two distinct parts. The first part of the requirement deals with circulating atmosphere between Node 1 and Node 3 , which is commonly called intermodule ventilation (IMV), and the second part of the requirement deals with circulating atmosphere within Node 1 , which is commonly called intramodule ventilation. The Node 1 intramodule ventilation is impacted by this change by the modification kit parts that were designed to cover both Node 1 aft port IMV diffusers so that the Russian Segment IMV air could be routed into Node 3 instead of using it to augment the Node 1 intramodule ventilation. Both parts of the requirements were re-verified by their separate sub-requirements and will be discussed below.

\begin{tabular}{|c|c|c|}
\hline \multicolumn{3}{|c|}{$\begin{array}{c}\text { S683-99600 } \\
\text { Table IX - } \\
\text { Interface Connector * }\end{array}$} \\
\hline Gender & Size & Keying \\
\hline Male & Code 2 & N/A \\
\hline
\end{tabular}

* - Connector at the bulkhead end of the flex hose is a Feedthrough fitting provided by the contractor as part of the Node 1 Modification Kit

Table 9b. Sample Distribution Line Flex Hose Interface Connector Requirement

\begin{tabular}{|l|l|}
\hline \multicolumn{1}{|c|}{$\begin{array}{c}\text { S684-12964 } \\
\text { Requirement }\end{array}$} & \multicolumn{1}{c|}{\begin{tabular}{c}
\multicolumn{1}{c|}{ S684-12964 } \\
Verification
\end{tabular}} \\
\hline $\begin{array}{l}\text { Node 3 Relocation } \\
\text { shall provide an } \\
\text { Atmospheric Sample } \\
\text { Port at Node 1 PORT } \\
\text { location (Node 3 } \\
\text { interface) as specified } \\
\text { in SSP 41141, }\end{array}$ & $\begin{array}{l}\text { Verification of the } \\
\text { distribution atmosphere } \\
\text { samples requirement } \\
\text { paragraph }\end{array}$ \\
$\begin{array}{l}\text { shall be performed by } \\
\text { analysis. Analysis of the }\end{array}$ & $\begin{array}{l}\text { Node 3 Relocation } \\
\text { drawings shall be } \\
\text { performed to determine } \\
\text { the pressure loss of the } \\
\text { jumper between the } \\
\text { Node 1 port and the } \\
\text { Node 3 bulkhead as } \\
\text { specified. }\end{array}$ \\
& $\begin{array}{l}\text { Verification shall be } \\
\text { considered successful } \\
\text { when the analysis shows } \\
\text { that the jumper } \\
\text { performance is as } \\
\text { specified in the ICD. }\end{array}$ \\
\hline
\end{tabular}

Table 10. Node 1 Sample Distribution Line Modification Kit Performance Requirement 


\section{Circulate Intermodule Ventilation:}

To meet the equipment requirements in Table 11, 12, 13 and 14 Boeing - Huntsville analyzed the modification kit ducting to make sure that it met the temperature requirement and flow rate requirement for the new ducting. They also performed an inspection of the drawings to show that the ducting was built so that it could attach to the existing Node 1 ducting and to the Node 1 bulkhead IMV pass through to allowing IMV air to be exchanged between Node 1 and Node 3. They also performed an inspection that showed that a new IMV remote manual override (RMO) could be added to Node 1 to allow the crew members to manually control the new IMV valve at the Node 1 port aft interface. The analysis (Ref. 17) and the inspection report (Ref. 18, 19, and 20) provided evidence on how these requirements were met.

The analysis showed that the flow rate part of the requirement was met by a development test and analysis of the results of that test, which will be discussed in the system level requirement write up below. It also showed that the temperature requirement was met based previous verification tasks that the IMV air from the Russian Segment to Pressurized Mating Adapter 1 (PMA 1) is between 18.3 to 28 degrees $\mathrm{C}$ ( 65 to 82.4 degrees F) and the Node 3 cabin air is maintained between 18.3 to 26.7 degrees C ( 65 to 80 degrees F) and the only heat source in the air flow stream is an IMV fan. The IMV fan would only increase the air temperature by 1.2 degrees $F$ above those interface temperatures.

The inspection reports showed that IMV ducting modification kit would mate with the existing IMV ducting, move an IMV valve from Node 1 nadir forward interface to Node 1 port aft interface, and caps off any unused IMV ducting. Also, the inspection reports showed that an IMV RMO can be added to the Node 1 port midbay to control the relocated IMV valve.

Based on the IMV ducting analysis and inspection results the IMV ducting met all of its requirements.

To meet the system level requirement in Table 15, Boeing - Huntsville first performed a development IMV flow test in the Node 1 and U.S. Laboratory Module Simulators at Marshall Space Flight Center (MSFC) (Ref. 21). The results from this development test showed that the pressure drops were less than the specified value and that the airflow exceeded the minimum specified value. Boeing - Houston then analytically adjusted these results by subtracting out the resistance of the

\begin{tabular}{|l|l|}
\hline \multicolumn{1}{|c|}{$\begin{array}{c}\text { S683-99605 } \\
\text { Requirement }\end{array}$} & \multicolumn{1}{c|}{$\begin{array}{c}\text { S683-99605 } \\
\text { Verification }\end{array}$} \\
\hline $\begin{array}{l}\text { The Node 1 IMV } \\
\text { Modification Kit } \\
\text { shall allow the Node } \\
3 \text { to receive/return } \\
\text { intermodule air } \\
\text { from/to the Node 1 at } \\
\text { a temperature } \\
\text { between 65 to 85 } \\
\text { degrees F and a } \\
\text { minimum flow rate of } \\
\text { 120 cubic feet per } \\
\text { minute (cfm). }\end{array}$ & $\begin{array}{l}\text { An analysis shall be performed to show } \\
\text { that the Node 1 IMV Modification Kit } \\
\text { allows the Node 3 to receive/return } \\
\text { intermodule air from/to the Node 1 at a } \\
\text { temperature between 65 to 85 degrees } \\
\text { F and minimum flow rate of 120 cfm. } \\
\text { The verification shall be considered } \\
\text { successful when the analysis shows } \\
\text { that the Node 1 IMV Modification Kit } \\
\text { provides intermodule air ducting } \\
\text { assemblies to allow distribution of } \\
\text { intermodule air between the Node 3 } \\
\text { and the Node 1 with the specified } \\
\text { characteristics. }\end{array}$ \\
\hline
\end{tabular}

Table 11. IMV Ducting Performance Requirement

\begin{tabular}{|l|l|}
\hline \multicolumn{1}{|c|}{$\begin{array}{c}\text { S683-99605 } \\
\text { Requirement }\end{array}$} & \multicolumn{1}{c|}{$\begin{array}{c}\text { S683-99605 } \\
\text { Verification }\end{array}$} \\
\hline $\begin{array}{l}\text { The Node 1 IMV } \\
\text { Modification Kit } \\
\text { shall provide ducting } \\
\text { to allow the } \\
\text { interconnection } \\
\text { between the Node 1 } \\
\begin{array}{l}\text { Port Alcove IMV } \\
\text { ducting and the Node }\end{array}\end{array}$ & $\begin{array}{l}\text { An inspection of Node 1 IMV } \\
\text { Modification Kit design drawings and } \\
\text { 1 Nadir Alcove IMV } \\
\text { show that the Node 1 IMV } \\
\text { ducting. }\end{array}$ \\
$\begin{array}{l}\text { Modification Kit provides an IMV } \\
\text { ducting assembly to allow the } \\
\text { interconnection between the Node 1 } \\
\text { Port Alcove IMV ducting and the Node } \\
\text { 1 Nadir Alcove IMV ducting. The } \\
\text { verification shall be considered } \\
\text { successful when the inspection shows } \\
\text { that the Node 1 IMV Modification Kit } \\
\text { provides a ducting assembly to allow } \\
\text { the interconnection between the Node 1 } \\
\text { Port Alcove IMV ducting and the Node } \\
\text { 1 Nadir Alcove IMV ducting. }\end{array}$ \\
\hline \multicolumn{2}{|l}{} \\
\hline
\end{tabular}

Table 12. IMV Return Ducting Interconnection Requirement 


\begin{tabular}{|l|l|}
\hline \multicolumn{1}{|c|}{$\begin{array}{c}\text { S683-99605 } \\
\text { Requirement }\end{array}$} & \multicolumn{1}{c|}{\begin{tabular}{c}
\multicolumn{1}{c}{ S683-99605 } \\
Verification
\end{tabular}} \\
\hline $\begin{array}{l}\text { The Node 1 IMV } \\
\text { Modification Kit } \\
\text { shall provide } \\
\text { ducting to allow the } \\
\text { interconnection } \\
\text { between the Node 1 } \\
\text { Port Midbay IMV } \\
\text { ducting and the } \\
\text { Node 1 Port } \\
\text { Bulkhead A04. }\end{array}$ & $\begin{array}{l}\text { An inspection of Node 1 } \\
\text { IMV Modification Kit } \\
\text { design drawings and } \\
\text { documentation shall be } \\
\text { performed to show that } \\
\text { the Node 1 IMV } \\
\text { Modification Kit } \\
\text { provides an IMV ducting } \\
\text { assembly to allow the } \\
\text { interconnection between } \\
\text { the Node 1 Port Midbay } \\
\text { IMV ducting and the } \\
\text { Node 1 Port Bulkhead } \\
\text { A04 connector. The } \\
\text { inspection shall show } \\
\text { that the ducting } \\
\text { assembly end connector } \\
\text { is compatible (size) to } \\
\text { the A04 connector. The } \\
\text { verification shall be } \\
\text { considered successful } \\
\text { when the inspection } \\
\text { shows that the Node 1 } \\
\text { IMV Modification Kit } \\
\text { provides a ducting } \\
\text { assembly to allow the } \\
\text { interconnection between } \\
\text { the Node 1 Port Midbay } \\
\text { IMV ducting and the } \\
\text { Node 1 Port Bulkhead } \\
\text { A04 connector. }\end{array}$ \\
\hline
\end{tabular}

Table 13. IMV Supply Ducting Interconnection Requirement

development level mufflers and a small part of the development ducting and added back the flight values since the flight mufflers and a small part of the flight ducting were not available at the time for the development test.

The result from the calculated pressure loss analysis for the IMV leg from PMA 1 to Node 3 showed that the system would flow 0.51 cubic meter/minute (18 cubic feet/minute $[\mathrm{cfm}])$ more than the specified value (Ref. 22). As for the IMV leg from Node 3 to the U.S. Laboratory Module the calculated pressure loss analysis showed that the system would flow 0.74 cubic meter/minute $(26 \mathrm{cfm})$ more than the specified value (Ref. 22).

Based on the analysis result, Node 1 IMV modifi-

\begin{tabular}{|c|c|}
\hline $\begin{array}{c}\text { S683-99605 } \\
\text { Requirement }\end{array}$ & $\begin{array}{l}\text { S683-99605 } \\
\text { Verification } \\
\end{array}$ \\
\hline $\begin{array}{l}\text { The Node } 1 \text { IMV } \\
\text { Modification Kit shall } \\
\text { provide an IMV RMO } \\
\text { handle assembly for the } \\
\text { Node } 1 \text { Port IMV } \\
\text { Return Duct Valve for } \\
\text { manual control of the } \\
\text { IMV airflow. }\end{array}$ & $\begin{array}{l}\text { An inspection of Node } 1 \\
\text { IMV Modification Kit } \\
\text { design drawings and } \\
\text { documentation shall be } \\
\text { performed to show that the } \\
\text { Node } 1 \text { IMV Modification } \\
\text { Kit provides an IMV RMO } \\
\text { handle assembly for the } \\
\text { Node } 1 \text { Port IMV Return } \\
\text { Duct Valve for manual } \\
\text { control of the IMV airflow. } \\
\text { The verification shall be } \\
\text { considered successful when } \\
\text { the inspection shows that the } \\
\text { Node } 1 \text { IMV Modification } \\
\text { Kit provides an IMV RMO } \\
\text { handle assembly for the } \\
\text { Node } 1 \text { Port IMV Return } \\
\text { Duct Valve. }\end{array}$ \\
\hline
\end{tabular}

Table 14. IMV RMO Interconnection Requirement

\begin{tabular}{|l|l|}
\hline \multicolumn{1}{|c|}{$\begin{array}{c}\text { S684-12964 } \\
\text { Requirement }\end{array}$} & \multicolumn{1}{c|}{$\begin{array}{c}\text { S684-12964 } \\
\text { Verification }\end{array}$} \\
\hline $\begin{array}{l}\text { Node 3 Relocation shall } \\
\text { provide IMV between } \\
\text { Node 1 and Node 3 as } \\
\text { specified in SSP 41140, } \\
\text { paragraphs 3.2.1.2.5.1.4 } \\
\text { and 3.2.1.2.6.1.4. }\end{array}$ & $\begin{array}{l}\text { The Node 3 Relocation } \\
\text { circulate atmosphere } \\
\text { intermodule requirement } \\
\text { shall be verified by analysis. } \\
\text { An analysis based on data } \\
\text { from development testing of } \\
\text { the Node 1 IMV } \\
\text { configuration shall be } \\
\text { performed to evaluate } \\
\text { pressure loss and flow rate } \\
\text { characteristics in the IMV } \\
\text { distribution ducts in } \\
\text { accordance with the } \\
\text { specified ICDs. } \\
\text { The verification shall be } \\
\text { considered successful when } \\
\text { the analysis shows that } \\
\text { interface conditions at Node } \\
1 \text { port location is satisfied in } \\
\text { accordance with the } \\
\text { reference ICDs. }\end{array}$ \\
\end{tabular}

Table 15. Node 1 IMV Modification Kit Performance Requirement

12

American Institute of Aeronautics and Astronautics 
cation kit met the pressure loss and flow rate requirement for the IMV ducting modification

\section{Circulate Intramodule Ventilation:}

To meet the equipment requirements in Table 16 Boeing - Huntsville performed an inspection of the drawings to show that they could cover the unused IMV diffusers. The inspection report (Ref. 23) provided evidence on how these requirements were met.

The inspection report showed that the unused IMV diffusers in the port midbay and the nadir alcove had covers that could be installed over them to prevent air flow from coming out of them when they are not being used. Based on the IMV diffuser inspection results the Node 1 IMV met its intramodule ventilation requirement.

To meet the system level requirement in Table 18, Boeing - Houston analyzed airflow velocities in Node 1 with and without airflow from the Joint Airlock to Node 1 using computational fluid dynamics (CFD). The result from the analysis showed that $72.7 \%$ of the Node 1 air velocities were in the $4.57-12.19$ meter/minute [meter/min] $(15$ - 40 feet/minute [fpm]) range when Node 1 was receiving IMV air from the Joint Airlock and $83.7 \%$ of the Node 1 air

\begin{tabular}{|c|c|c|}
\hline $\begin{array}{c}\text { Velocity } \\
\text { meter/min } \\
(\mathbf{f p m})\end{array}$ & $\begin{array}{c}\text { Airflow } \\
\text { from } \\
\text { Joint } \\
\text { Airlock }\end{array}$ & $\begin{array}{c}\text { No } \\
\text { Airflow } \\
\text { from Joint } \\
\text { Airlock }\end{array}$ \\
\hline $\begin{array}{c}<2.13 \\
(<7)\end{array}$ & $0.1 \%$ & $4.7 \%$ \\
\hline $\begin{array}{c}2.13- \\
4.57 / 3.05 * \\
\left(7-10 / 15^{*}\right)\end{array}$ & $3.6 \%$ & $6.2 \%$ \\
\hline $\begin{array}{c}4.57 / 3.05^{*}- \\
12.19 \\
(10 / 15 *-40)\end{array}$ & $72.7 \%$ & $83.7 \%$ \\
\hline $\begin{array}{c}12.19-60.96 \\
(40-200)\end{array}$ & $23.4 \%$ & $5.4 \%$ \\
\hline $\begin{array}{c}>60.96 \\
(>200)\end{array}$ & $0.2 \%$ & $0.0 \%$ \\
\hline
\end{tabular}

Table 17. Node 1 Airflow Analysis Results

* The lower value is used when there is no airflow from the Joint Airlock

\begin{tabular}{|l|l|}
\hline \multicolumn{1}{|c|}{$\begin{array}{c}\text { S683-99605 } \\
\text { Requirement }\end{array}$} & \multicolumn{1}{c|}{\begin{tabular}{c}
\multicolumn{1}{c|}{ S683-99605 } \\
Verification
\end{tabular}} \\
\hline $\begin{array}{l}\text { The Node 1 IMV } \\
\text { Modification Kit } \\
\text { shall provide cover } \\
\text { assemblies for the } \\
\text { IMV diffuser }\end{array}$ & $\begin{array}{l}\text { An inspection of Node 1 IMV } \\
\text { Modification Kit design drawings and } \\
\text { assemblies in the } \\
\text { documentation shall be performed to } \\
\text { show that the Node 1 IMV } \\
\text { and Nadir Alcove } \\
\text { locations to } \\
\text { accommodate the } \\
\text { new Node 1 IMV } \\
\text { aucting. }\end{array}$ \\
$\begin{array}{l}\text { assemblies for the IMV diffuser } \\
\text { assemblies in the Node 1 Port Midbay } \\
\text { and Nadir Alcove locations to } \\
\text { accommodate the new Node 1 IMV } \\
\text { ducting. The inspection shall show that } \\
\text { the cover assemblies are dimensionally } \\
\text { compatible with the on-orbit Node 1 } \\
\text { diffuser assemblies. The verification } \\
\text { shall be considered successful when the } \\
\text { inspection shows that the Node 1 IMV } \\
\text { Modification Kit provides cover } \\
\text { assemblies for the IMV diffuser } \\
\text { assemblies in the Node 1 Port Midbay } \\
\text { and Nadir Alcove locations to } \\
\text { accommodate the new Node 1 IMV } \\
\text { ducting. }\end{array}$ \\
\hline
\end{tabular}

Table 16. IMV Diffuser Cover Requirement

\begin{tabular}{|c|c|}
\hline $\begin{array}{c}\text { S684-12964 } \\
\text { Requirement } \\
\end{array}$ & $\begin{array}{l}\text { S684-12964 } \\
\text { Verification } \\
\end{array}$ \\
\hline $\begin{array}{l}\text { a. Node } 3 \text { Relocation } \\
\text { shall maintain the } \\
\text { Node } 1 \text { effective } \\
\text { atmosphere velocity } \\
\text { in the Node } 1 \text { cabin } \\
\text { aisleway in the range } \\
\text { of } 15 \text { to } 40 \text { feet per } \\
\text { minute. } \\
\text { b. During periods } \\
\text { when intermodule } \\
\text { atmosphere exchange } \\
\text { with the Airlock is } \\
\text { non-functional, } \\
\text { effective velocity } \\
\text { shall be } 10-40 \text { feet } \\
\text { per minute. }\end{array}$ & $\begin{array}{l}\text { a. and b.: The Node } 3 \text { Relocation } \\
\text { capability to maintain an effective } \\
\text { cabin aisleway circulation velocities in } \\
\text { the range of } 15-40 \text { feet per minute (10- } \\
40 \text { feet per minute during periods when } \\
\text { intermodule atmosphere exchange with } \\
\text { the Airlock is non functional) shall be } \\
\text { verified by analysis. The analysis shall } \\
\text { be performed considering the Node } 1 \\
\text { internal geometric configuration with } \\
\text { proper locations of diffusers and } \\
\text { registers, and the effect of the IMV } \\
\text { velocities. The verification shall be } \\
\text { considered successful when the } \\
\text { analysis proves that the specified } \\
\text { velocity ranges are maintained. }\end{array}$ \\
\hline
\end{tabular}

Table 18. Node 1 Intramodule Ventilation Performance Requirement

13

American Institute of Aeronautics and Astronautics 
velocities were in the $3.05-12.19$ meter/min $(10-40 \mathrm{fpm})$ range when Node 1 was not receiving IMV air from the Joint Airlock, as shown in Table 17 (Ref. 24). Based on the analysis result, Node 1 intramodule ventilation meet its air velocity requirements with the modification kit installed.

\section{Node 1 WRM Re-Verification Methodology:}

\section{Distribute Waste Water:}

To meet the equipment requirements in Table 19, 20a, and 20b, Boeing Huntsville analyzed the modification kit hose to make sure that the hardware had the proper length, met the proof pressure requirement, met the temperature requirement, and calculated the pressure drop for the new flex hose. They also performed an inspection of the drawings to show that the flex hose was built with the correct connectors at both ends of the hose. The analysis (Ref. 25) and the inspection report (Ref. 26) provided evidence on how these requirements were met.

The analysis showed that the length of the new hose was adequate based on a CAD drawing, review of the hose vendor acceptance data package measurement, and a fit check in the Node 1 mockup that was performed on September 3, 2008. It also showed that the proof pressure and temperature requirements were met based on the hose vendor proof pressure and thermal cycle test data. The hose pressure loss was calculated to be $0.93 \mathrm{kPa}$ differential (0.135 psid), which was then used in the system analysis that was performed by Boeing - Huntsville and Boeing - Houston.

The inspection report showed that QD and the gamah fitting on the ends of the hose would mate with the existing Node 1 waste water distribution and the new vestibule jumper hose.

Based on the flex hose analysis and inspection results the flex hose met all of its requirements.

To meet the system level requirement in Table 21, Boeing Huntsville and Boeing - Houston

analyzed the pressure loss of the of the Node 1 waste water distribution from the Node 1 starboard and forward interfaces to the Node 1 port interface at the maximum specified flow rate, temperature, and the initial nominal pressure as specified in the original verification for Node 1 (Ref. 5). The result from the calculated pressure loss analysis for the waste water distribution showed that the pressure loss was $1.84 \mathrm{kPa}$ differential $(0.267 \mathrm{psid})$ for the

\begin{tabular}{|c|c|}
\hline $\begin{array}{c}\text { S683-99600 } \\
\text { Requirement } \\
\end{array}$ & $\begin{array}{l}\text { S683-99600 } \\
\text { Verification }\end{array}$ \\
\hline $\begin{array}{l}\text { The Node } 1 \\
\text { Modification Kit } \\
\text { shall allow the Node } \\
3 \text { to receive/return } \\
\text { waste water from/to } \\
\text { the Node } 1 \text { with the } \\
\text { following } \\
\text { temperature, } \\
\text { pressure, and flow } \\
\text { rate characteristics: } \\
33 \text { to } 113 \text { degrees } \mathrm{F} \text {, } \\
0 \text { to } 8 \text { psig }(85 \text { psig } \\
\mathrm{MDP}) \text {, and } 0 \text { to } 132 \\
\mathrm{lb} / \mathrm{hr} \text {. }\end{array}$ & $\begin{array}{l}\text { An analysis shall be performed to show } \\
\text { that the Node } 1 \text { Modification Kit } \\
\text { allows the Node } 3 \text { to receive/return } \\
\text { waste water from/to the Node } 1 \text { with } \\
\text { the following temperature, pressure, } \\
\text { and flow rate characteristics: } 33 \text { to } 113 \\
\text { degrees F, } 0 \text { to } 8 \text { psig ( } 85 \text { psig MDP), } \\
\text { and } 0 \text { to } 132 \mathrm{lb} / \mathrm{hr} \text {. The analysis shall } \\
\text { show that the Node } 1 \text { Modification Kit } \\
\text { contains a hose assembly with proper } \\
\text { length to allow the interconnection } \\
\text { between the Node } 1 \text { Nadir Midbay } \\
\text { Waste Water Bus and the Node } 1 \text { Port } \\
\text { Bulkhead J30 connector. The analysis } \\
\text { shall evaluate vendor proof pressure } \\
\text { test results for the Node } 1 \text { Modification } \\
\text { Kit waste water hose assembly to } \\
\text { verify that the hose was successfully } \\
\text { tested at } 170 \text { psig ( } 2 \text { xMDP) in } \\
\text { accordance with SSP } 30559 \text {. A } \\
\text { pressure drop analysis shall be } \\
\text { conducted to show that the Node } 1 \\
\text { Modification Kit waste water hose can } \\
\text { distribute waste water at a flow rate of } \\
132 \text { lb/hr. The analysis shall also } \\
\text { evaluate vendor documentation to show } \\
\text { that the hose is compatible with a } \\
\text { temperature range of } 33 \text { to } 113 \text { degrees } \\
\text { F. The verification shall be considered } \\
\text { successful when the analysis shows } \\
\text { that the Node } 1 \text { Modification Kit } \\
\text { provides a waste water hose assembly } \\
\text { to allow waste water interconnection } \\
\text { with the specified characteristics. }\end{array}$ \\
\hline
\end{tabular}

Table 19. Waste Water Flex Hose Performance Requirement 


\begin{tabular}{|l|l|}
\hline \multicolumn{1}{|c|}{$\begin{array}{c}\text { S683-99600 } \\
\text { Requirement }\end{array}$} & \multicolumn{1}{c|}{\begin{tabular}{c}
\multicolumn{1}{c}{ S683-99600 } \\
Verification
\end{tabular}} \\
\hline $\begin{array}{l}\text { The Node 1 } \\
\text { Modification Kit } \\
\text { shall provide a } \\
\text { hose to allow the } \\
\text { interconnection } \\
\text { between the Node } \\
\text { 1 Nadir Midbay } \\
\text { Waste Water Bus } \\
\text { connector and the } \\
\text { Node 1 Port } \\
\text { Bulkhead J30 } \\
\text { connector defined } \\
\text { in Table IX. }\end{array}$ & $\begin{array}{l}\text { Modification Kit design drawings } \\
\text { and documentation shall be } \\
\text { performed to show that the Node 1 } \\
\text { Modification Kit provides a hose } \\
\text { assembly to allow the } \\
\text { interconnection between the Node 1 } \\
\text { Nadir Midbay Waste Water Bus } \\
\text { connector and the Node 1 Port } \\
\text { Bulkhead J30 connector defined in } \\
\text { Table IX. The inspection shall } \\
\text { show that the hose assembly end } \\
\text { connectors are compatible (gender, } \\
\text { size and keying) to the supply/end } \\
\text { item connectors defined in Table } \\
\text { IX. The verification shall be } \\
\text { considered successful when the } \\
\text { inspection shows that the Node 1 } \\
\text { Modification Kit provides a hose } \\
\text { assembly compatible with the waste } \\
\text { water interface defined in Table IX. }\end{array}$ \\
& \multicolumn{2}{|c|}{} \\
\hline
\end{tabular}

Table 20a. Waste Water Flex Hose Interconnection Requirement

\begin{tabular}{|c|c|c|}
\hline \multicolumn{3}{|c|}{$\begin{array}{c}\text { S683-99600 } \\
\text { Table IX - } \\
\text { Interface Connector * }\end{array}$} \\
\hline Gender & Size & Keying \\
\hline Male & 0.500 inch & $\begin{array}{c}\text { E (165 } \\
\text { degrees) }\end{array}$ \\
\hline
\end{tabular}

* - Connector at the bulkhead end of the flex hose is a Feedthrough fitting provided by the contractor as part of the Node 1 Modification Kit

\section{Table 20b. Waste Water Flex Hose Interface Connector Requirement}

forward interface to the port interface and was $1.66 \mathrm{kPa}$ differential $(0.241 \mathrm{psid})$ for the starboard interface to the port interface (Ref. 27 and 28). This new analysis was performed slightly different than the original Node 1 verification analysis. The difference was that Boeing Huntsville and Boeing - Houston used a more realistic friction factor for the flex hoses than the original Node 1 analysis. For this analysis they used a friction factor of two times the friction factor of an equivalent length

\begin{tabular}{|c|c|}
\hline $\begin{array}{c}\text { S684-12964 } \\
\text { Requirement }\end{array}$ & $\begin{array}{c}\text { S684-12964 } \\
\text { Verification } \\
\end{array}$ \\
\hline $\begin{array}{l}\text { Node } 3 \text { Relocation } \\
\text { shall provide Waste } \\
\text { Water at Node } 1 \\
\text { PORT location (Node } \\
3 \text { interface) as } \\
\text { specified in SSP } \\
41140 \text {, paragraph } \\
3.2 .1 .2 .8 \text {. }\end{array}$ & $\begin{array}{l}\text { The Node } 3 \text { Relocation } \\
\text { distribute waste water } \\
\text { requirement shall be } \\
\text { verified by inspection and } \\
\text { analysis. An inspection of } \\
\text { Node } 3 \text { Relocation } \\
\text { drawings shall be } \\
\text { performed to verify the } \\
\text { existence of waste water } \\
\text { distribution. } \\
\text { An analysis of the waste } \\
\text { water distribution shall be } \\
\text { performed to determine } \\
\text { the pressure loss } \\
\text { characteristics considering } \\
\text { the temperature, pressure, } \\
\text { and flow rate specified in } \\
\text { the ICD. An analysis shall } \\
\text { also consider the } \\
\text { proximity of thermal } \\
\text { sources to the location of } \\
\text { the waste water } \\
\text { distribution to verify that } \\
\text { the temperature is } \\
\text { maintained as specified in } \\
\text { the ICD. } \\
\text { The verification shall be } \\
\text { considered successful } \\
\text { when the inspection } \\
\text { identifies waste water } \\
\text { distribution as follows: (1) } \\
\text { USL interface to Node } 3 \\
\text { interface, (2) Node } 3 \\
\text { interface to USL interface, } \\
\text { (3) Airlock interface to } \\
\text { USL interface, and (4) } \\
\text { Airlock interface to Node } \\
\text { outlet temperature range is } \\
\text { the ICD. } \\
\text { analysis proves that when } \\
\text { (1) given the ICD } \\
\text { temperature, pressure, and } \\
\text { flow rate, the resulting } \\
\text { pressure loss in Node } 1 \text { is } \\
\text { as specified in the ICD; } \\
\text { and (2) given the input } \\
\text { ICmperature ranges in the } \\
\text { locified in } \\
\text { and the distribution } \\
\text { anden the }\end{array}$ \\
\hline
\end{tabular}

Table 21. Node 1 Waste Water Modification Kit Performance Requirement 
smooth tube instead of four times that was used in the original verification analysis. Even with the change the analysis result is still considered to be slightly conservative since Boeing - Huntsville and Boeing - Houston used the QD specified pressure drop data in the analysis, which is higher than the actual Qualification data as discussed in the original verification for Node 1.

Based on the analysis result, Node 1 modification kit met the pressure loss requirement for the waste water distribution.

\section{Distribute Fuel Cell Water:}

To meet the equipment requirements in Table 22, 23a, and 23b, Boeing Huntsville analyzed the modification kit hose to make sure that the hardware had the proper length, met the proof pressure requirement, and met the temperature requirement. Based on a water supply pressure non-compliance report (NCR) Boeing - Huntsville had the vendor increase the proof pressure of the flex hose to $262.01 \mathrm{kPa}$ gauge (38 pound/inch ${ }^{2}$ gauge [psig]) instead of $241.33 \mathrm{kPa}$ gauge (35 psig), as called out in the requirement. They also performed an inspection of the drawings to show that the flex hose was built with the correct connectors at both ends of the hose. The analysis (Ref. 29) and the inspection report (Ref. 30) provided evidence on how these requirements were met.

The analysis showed that the length of the new hose was adequate based on a CAD drawing, review of the hose vendor acceptance data package measurement, and a fit check in the Node 1 mockup that was performed on September 4, 2008. It also showed that the proof pressure and temperature requirements were met based on the hose vendor proof pressure and thermal cycle test data.

The inspection report showed that QD and the gamah fitting on the ends of the hose would mate with the existing Node 1 waste water distribution and the new vestibule jumper hose.

Based on the flex hose analysis and inspection results the flex hose met all of its requirements.

To meet the system level requirement in Table 24, Boeing - Huntsville and Boeing - Houston analyzed the pressure loss of the of the Node 1 fuel cell water distribution from the Node 1 forward interface to the Node 1 port interface at the maximum specified flow rate, temperature, and the initial nominal pressure as specified in the original verification for Node 1 (Ref. 5). The result from the calculated pressure loss analysis for the fuel cell water distribution showed that the pressure loss was $\mathrm{x} . \mathrm{xx} \mathrm{kPa}$ differential (0.xxx psid) for the forward interface to the port interface (Ref. 27 and 31). This new analysis was performed slightly different than the original Node 1 verification analysis. The difference was that Boeing - Huntsville and Boeing - Houston used a more realistic friction factor for the flex hoses than the original Node 1 analysis. For this analysis they used a friction factor of two times the friction 


\begin{tabular}{|l|l|}
\hline \multicolumn{1}{|c|}{$\begin{array}{c}\text { S683-99600 } \\
\text { Requirement }\end{array}$} & \multicolumn{1}{c|}{\begin{tabular}{c}
\multicolumn{1}{c}{ S683-99600 } \\
Verification
\end{tabular}} \\
\hline $\begin{array}{l}\text { The Node 1 } \\
\text { Modification Kit } \\
\text { shall provide a } \\
\text { hose to allow the } \\
\text { interconnection } \\
\text { between the Node } \\
\text { 1 Nadir Midbay } \\
\text { Fuel Cell Bus } \\
\text { connector and the } \\
\text { Node 1 Port } \\
\text { Bulkhead J33 } \\
\text { connector defined } \\
\text { in Table IX. }\end{array}$ & $\begin{array}{l}\text { An inspection of Node 1 } \\
\text { and documentation shall be } \\
\text { performed to show that the Node 1 } \\
\text { assembly to allow the } \\
\text { interconnection between the Node 1 } \\
\text { Nadir Midbay Fuel Cell Bus } \\
\text { connector and the Node 1 Port } \\
\text { Bulkhead J33 connector defined in } \\
\text { Table IX. The inspection shall } \\
\text { show that the hose assembly end } \\
\text { connectors are compatible (gender, } \\
\text { size and keying) to the supply/end } \\
\text { item connectors defined in Table } \\
\text { IX. The verification shall be } \\
\text { considered successful when the } \\
\text { inspection shows that the Node 1 } \\
\text { Modification Kit provides a hose } \\
\text { assembly compatible with the fuel } \\
\text { cell water interface defined in Table } \\
\text { IX. }\end{array}$ \\
\hline
\end{tabular}

Table 23a. Fuel Cell Water Flex Hose Interconnection Requirement

\begin{tabular}{|c|c|c|}
\hline \multicolumn{3}{|c|}{$\begin{array}{c}\text { S683-99600 } \\
\text { Table IX - } \\
\text { Interface Connector * }\end{array}$} \\
\hline Gender & Size & Keying \\
\hline Male & 0.500 inch & $\begin{array}{c}\text { F (195 } \\
\text { degrees) }\end{array}$ \\
\hline
\end{tabular}

* - Connector at the bulkhead end of the flex hose is a Feedthrough fitting provided by the contractor as part of the Node 1 Modification Kit

\section{Table 23b. Fuel Cell Water Flex Hose Interface Connector Requirement}

factor of an equivalent length smooth tube instead of four times that was used in the original verification analysis. Even with the change the analysis result is still considered to be slightly conservative since Boeing - Huntsville and Boeing - Houston used the QD specified pressure drop data in the analysis, which is higher than the actual Qualification data as discussed in the original verification for Node 1 .

\begin{tabular}{|c|c|}
\hline $\begin{array}{c}\text { S684-12964 } \\
\text { Requirement }\end{array}$ & $\begin{array}{c}\text { S684-12964 } \\
\text { Verification } \\
\end{array}$ \\
\hline $\begin{array}{l}\text { Node } 3 \text { Relocation } \\
\text { shall provide Fuel Cell } \\
\text { Water at Node } 1 \\
\text { PORT location (Node } \\
3 \text { interface) as } \\
\text { specified in SSP } \\
41140 \text {, paragraph } \\
3.2 .1 .2 .11 \text {. }\end{array}$ & 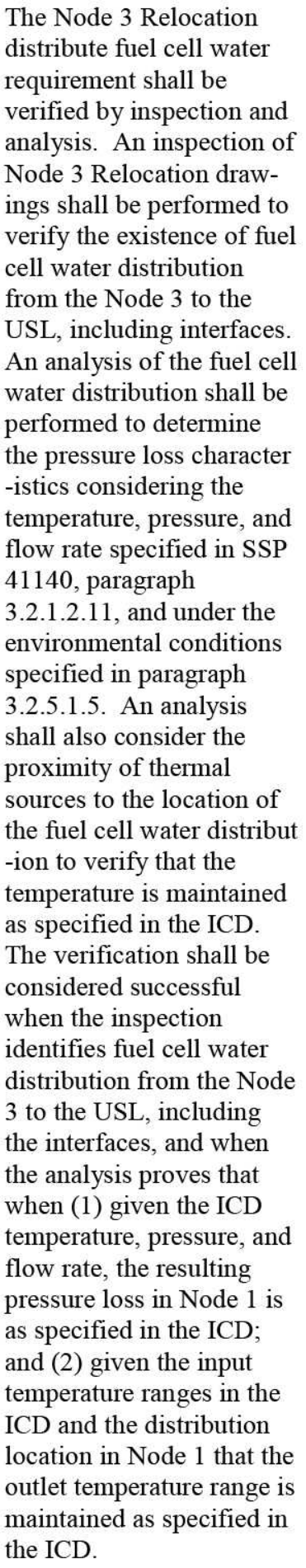 \\
\hline
\end{tabular}

Table 24. Node 1 Fuel Cell Water Modification Kit Performance Requirement 
Based on the analysis result, Node 1 modification kit met the pressure loss requirement for the fuel cell water distribution.

\section{Delivery and Installation of the Node 1 Modification Kit}

Need to finish writing up this section ....

\section{Conclusion}

This paper provided a general overview of the Node 1 ECLS design and the changes that were made to support the movement of Node 1 from the nadir docking location to the port docking location. It also provided a summary of the verification of the Node 1 modification kit utilizing a building block approach from the equipment level to the integrated Node 1 re-verification. It showed that the modification kit and the Node 1 re-verification satisfactorily met all of its requirements. Finally, the paper also provided an overview of the delivery and installation of the Node 1 modification kit to allow the installation of Node 3 and Cupola to Node 1 on Flight 20A.

\section{Acknowledgements}

This project could not have been completed without the hard work of Boeing - Huntsville engineers Jim Hodgins, Boris Simmonds, James Byrd, and Roger von Jouanne and Boeing - Houston engineers Amber Wilson, Ryan Schaezler, Ed Turner, Ara Kulhanjian, and Chang Son.

\section{References}

1. "Specification for Node 3 Relocation"; S684-12964, Revision A; February 1, 2010.

2. "Critical Item Development Specification for the Node 1 Modification Kit to Accommodate Node 3 Relocation from Node 1 Nadir to Node 1 Port"; S683-99600; Revision B; June 26, 2009.

3. "Critical Item Development Specification for the Node 1 Intermodule Ventilation (IMV) Modification Kit to Accommodate Node 3 Relocation from Node 1 Nadir to Node 1 Port"; S683-99605; Revision B; July 28, 2009.

4. Dwight E. Link, Jr., David E. Williams; "Modification of the USOS to Support Installation and Activation of the Node 3 Element"; SAE 2009-01-2416; $39^{\text {th }}$ International Conference on Environmental Systems; Savannah, Ga.; July 2009.

5. David E. Williams; "International Space Station Atmosphere Control and Supply, Atmosphere Revitalization, and Water Recovery and Management Subsystem - Verification for Node 1"; SAE 2007-01-3102; $37^{\text {th }}$ International Conference on Environmental Systems; Chicago Il.; July 2007.

6. David E. Williams; "International Space Station Temperature and Humidity Control Subsystem Verification for Node 1"; SAE 2007-01-3185; 37 International Conference on Environmental Systems; Chicago Il.; July 2007.

7. David E. Williams; "International Space Station Environmental Control and Life Support Emergency Response Verification for Node 1"; SAE 2008-01-2136; $38^{\text {th }}$ International Conference on Environmental Systems; San Francisco, Ca.; June and July 2008.

8. Boris G. Simmonds; "3.2.1.3.1, (340) [21088] Distribute nitrogen"; Revised; August 5, 2009.

9. Boris G. Simmonds; "3.2.2.3.1, (340) [21102] Nitrogen interface”; Initial Release; June 18, 2009.

10. Ryan N. Schaezler; "Pressure Drop Analysis for Oxygen and Nitrogen Distribution"; EID 684-12331 Revision - Initial; October 27, 2008.

11. Boris G. Simmonds; "3.2.1.3.2, (350) [21089] Distribute oxygen"; Revised; August 5, 2009.

12. James Byrd; "3.2.2.3.2.1, (531) [21251] Oxygen line clearance"; Initial Release; July 14, 2009.

13. Boris G. Simmonds; "3.2.2.3.2, (1) [21103] Oxygen interface"; Initial Release; June 18, 2009.

14. Boris G. Simmonds; "3.2.1.3.5, (400) [21094] Distribute atmosphere sample air"; Revised; August 5, 2009.

15. Boris G. Simmonds; "3.2.2.3.5, (1) [21106] Atmosphere sample air interface”; Revised; July 27, 2009.

16. Edward H. Turner; "Pressure Drop in Sample Delivery System (SDS) With Node 3 Relocation to Node 1 Port Hatch"; EID 684-12333 Revision - Initial; October 27, 2008.

17. Roger von Jouanne; "3.2.1.3.1, (300) [22604] Distribute intermodule atmosphere"; Initial Release; August 6, 2009.

18. Boris G. Simmonds; "3.2.2.3.1.1, (400) [21997] IMV return interface”; Initial Release; June 11, 2009.

19. Boris G. Simmonds; "3.2.2.3.1.2, (440) [21998] IMV supply interface”; Initial Release; August 6, 2009.

20. James Byrd; "3.2.2.4.1, (1) [21999] IMV RMO control”; Initial Release; April 8, 2009.

21. Roger G. von Jouanne; "Node 3 Relocation Phase II Test Report; IMV Measurements to/from Node 3EID 684-12369 Revision - Initial; December 18, 2008.

22. Edward H. Turner; "Node 3 IMV Pressure Drop Adjustments"; EID 684-12372 Revision - Initial; December 17, 2008.

23. James Byrd; "3.2.2.4.3, (1) [22001] Node 1 IMV diffuser covers"; Initial Release; April 8, 2009.

24. Chang Son; "Analyze Integrated Ventilation CFD Abstract for 20A (TDS VM 25.1-62)"; EID 684-13484 Revision Initial; June 10, 2009.

25. Roger von Jouanne; “3.2.1.3.3, (360) [21090] Distribute waste water”; Revised; July 31, 2009. 
26. Boris G. Simmonds; "3.2.2.3.3, (1) [21104] Waste water interface"; Revised; June 9, 2009.

27. Boris G. Simmonds; "Waste water, VCN-12964-50 and Fuel cell water VCN-12964-51 Verification Requirement Report (S684-12964, VO 3.2.1.7.1 and VO 3.2.1.7.2)"; EID 683-13296; Revision - Initial; July 7, 2009.

28. Ara Kulhanjian; "ISS Verification for 20A \& ULF2 Waste Water Delta Pressure (VM.25.1-59)"; EID 684-12285; Revision - Initial; October 23, 2008.

29. Roger von Jouanne; “3.2.1.3.4, (1) [21092] Distribute fuel cell water”; Revised; August 4, 2009.

30. Boris G. Simmonds; "3.2.2.3.4, (1) [21105] Fuel cell water interface"; Revised; April 17, 2009.

31. Ara Kulhanjian; "ISS Verification for 20A \& ULF2 Fuel Cell Water Delta Pressure (VM.25.1-63)"; EID 684-12284; Revision - Initial; October 23, 2008. 